\title{
The Main Factors Should Be Considered by TNCS to Choose a Country as Emerging Market
}

\author{
Shiqi Huang, Baihao Ruan \\ Guangdong University of Technology, Guangzhou, China \\ Email: 504743033@qq.com
}

Received 10 May 2014; revised 10 June 2014; accepted 30 June 2014

Copyright (C) 2014 by authors and Scientific Research Publishing Inc.

This work is licensed under the Creative Commons Attribution International License (CC BY). http://creativecommons.org/licenses/by/4.0/

c) (i) Open Access

\section{Abstract}

This paper is to valuate the main factors that should be considered by TNCS (transnational corporations) when they want to choose a country as emerging market. The main factors include the advantages of TNCS as well as the key conditions of the country. This paper takes the Wal-Mart for example, as the Wal-Mart is the representative transnational corporation, which chose China as emerging market years ago, and grows to an efficient scale now. This paper firstly uses the Eclectic Theory to analyze the advantages of the Wal-Mart, and secondly uses the Porter diamond Model to analyze environment in China. The conclusion of report will get ideas for TNCS to evaluate whether a country is qualified for an emerging market more efficiently.

\section{Keywords}

\section{Emerging Markets, Transnational Corporations, China, Wal-Mart}

\section{Introduction}

Emerging market is a key which attracts FDI (Foreign Direct Investment). The four largest emerging markets are the BRIC countries (Brazil, Russia, India and China). However, China is also the largest developing country. Financial Times in 2013 reported that, according to the data of Chinese government, gross value of imports and exports reached US \$4.16 trillion in 2013. A data showed US international trade was US \$3.57 trillion in 2013. It means that China is basically the biggest trading nation in the world. In 2010 China replaced Japan as the world's No. 2 trader. Chinese economy was tow times than that of Japan in 2013. It is predicted that the gross of Chinese economy will grow US \$10 trillion. Hence, China, a very potential developing country, is a good choice for FDI (Foreign Direct Investment). The essay will take China as selected market and Wal-Mart as an example 
of TNCS (Transnational Corporations) to analyze the main factors into an emerging market country.

A country is whether or not considered as an emerging market. It means that it is whether or not worth to be invested. When enterprises meet the three advantages of the OLI Paradigm, emerging markets have the conditions of FDI. So the essay firstly will use the Eclectic Theory to analyze in the term of ownership advantages, location advantages and internalization advantages. Then it takes advantages of Porter diamond Model to analyze environment in China.

\section{The Eclectic Theory}

Dunning in 1977 developed the "OLI" or "eclectic" approach to the study of foreign direct investment (FDI). It has proved an extremely fruitful way of thinking about multinational enterprises (TNCSs) and has inspired a great deal of applied work in economics and international business.

"OLI" stands for Ownership, Location, and Internalization. It makes a decision that a firm becomes a multinational, depending on three potential sources advantage of "OLI". Ownership advantages explain why firms could go abroad, and suggest that successful TNCs should have specific advantages in order to overcome the operating costs in market countries. Location advantages are to help TNCS how to locate. Internalization advantages decide operating way of company in an emerging market. The feature of "OLI" approach is now standard in international trade theory [1].

\subsection{Ownership Advantages}

Ownership advantages explain the existence of TNCS. A key idea is that firms are collections of assets, and that candidate TNCS possesses higher-than-average levels of assets having the character of internal public goods. These assets can be applied to production at different locations; however, it does not reduce effectiveness.

There are different factors that a company should consider to expand foreign market, such as Wal-Mart's economic strength, influence and special management model.

It is the first to see the scale and finance of Wal-Mart Company. Wal-Mart Stores is an American multinational retailer corporation that runs chains of large discount general shops and warehouse stores. It is the third largest public corporation in the world. It owns over 2 million employees, and is the largest retailer in the world. Wal-Mart is also the largest grocery retailer in the United States. In 2009, it created 51\% of its US $\$ 258$ billion sales in the US from grocery business [2].

Statistic brain (2013) gave Wal-Mart Company Statistics (Table 1). The data which Table 1 shows reflected

Table 1. Table type styles. Wal-Mart statistics in 2013.

\begin{tabular}{|c|c|}
\hline Wal-Mart Statistics & Data \\
\hline Total amount of money spent at Wal-Mart every hour of every day & $\$ 36,000,000$ \\
\hline Total amount of profit Wal-Mart makes every minute & $\$ 34,880$ \\
\hline Total number of employees & $2,000,000$ \\
\hline Total number of stores & 4253 \\
\hline Percentage of Americans that live within 15 minutes of Wal-Mart & $90 \%$ \\
\hline Total sales annually & \$405 Billion \\
\hline Total number of Wal-Mart Brands & 27 \\
\hline Average amount of square feet per Wal-Mart Supercenter & 197,000 square feet \\
\hline Amount per every US dollar spent at Wal-Mart & 8 cents \\
\hline Total number of customers per week & $100,000,000$ \\
\hline World Rank by economy if Wal-Mart were a country & 19th \\
\hline Percent of Wal-Mart cashiers that are women & $72 \%$ \\
\hline Percent of purchases made by families making less than $\$ 40,000$ annually & $42 \%$ \\
\hline Percent of Wal-Mart suppliers located in China & $80 \%$ \\
\hline
\end{tabular}

(Source: Adapted from statistic brain, 2013, Available at: http://www.statisticbrain.com/wal-mart-company-statistics/) 
Wal-Mart's operating ability. It is noticeable that last one date shows 80 percent of Wal-Mart suppliers located in China. It means that Wal-Mart pays more attention to Chinese market.

Secondly, they have unique technical and management advantages. It takes Supply Chain Management of Wal-Mart as an example, because the management of its supply chain is a key that Wal-Mart becomes a dominant force in a competitive global market. University Alliance (2014) also stressed that Wal-Mart's Supply Chain Management plays important role. This management strategy can lead to lower product costs and reduce goods in stock carrying costs, improved in-store selection, and competitive pricing for the consumer. It is called "Wal-Mart-SCM-strategies". Its four components are vendor partnerships, cross docking and distribution management, technology, and integration. Wal-Mart can find suitable suppliers who ensure products at the best price. Then Wal-Mart establishes strategic partnerships with most of their vendors, offering them the potential for long-term and high volume purchases in exchange for the lowest possible prices [3]. It is decided that the advanced management advantages of Wal-Mart are to expand Chinese marketing.

\subsection{Location Advantages}

Dunning (1977) stressed the three conditions of location advantages. It includes labor cost, market potential, trade barriers and government policy.

\subsubsection{Labor Cost}

Some surveys found that wages in China have already risen by $10 \%$ in 2013. Some doubts the end of Chinese cheap labor. Chinese wages may be climbing rapidly, but Chinese productivity should be considered. The increasing numbers are controversial, but the trend is not. Chinese workers are paid more because they can produce more. For example, Chinese labor pool is huge and flexible, their working time is midnight in response to sudden demand. Secondly, right way to measure manufacturing competitiveness is not just by comparing labor costs, but by comparing entire supply chains. China's supply chain is sophisticated and supple. For example, even if labor costs are a quarter of those in China to make a given product, the unreliability or unavailability of many components may make it uneconomic to make things elsewhere. Wal-Mart also has own production line. Hence, Chinese labor cost is fit and helpful for Wal-Mart.

\subsubsection{Market Potential}

Xinhua News (2014) reported the data of retail sales in China that, in the first 11 months of 2013, retail sales grew 13 percent and the retail sales in November alone was up 13.7 percent year on year, which is the highest rate of increase this year.

National Bureau of Statistics of China (2014) also offered the relevant data. In 2013, the total retail sales of consumer goods accomplished 23438 billion Yuan, up 13.1 percent year-on-year. From another angle, different areas, in 2013, the retail sales of consumer goods in cities was 20246.2 billion Yuan, up 12.9 percent, year-onyear; while that in rural areas was 3191.8 billion Yuan, up 14.6 percent, year-on-year. According to different consumption patterns, in 2013, the catering services achieved 2539.2 billion Yuan, up 9.0 percent, year-on-year; the retail sales of goods gained 20898.8 billion Yuan, up 13.6 percent, year-on-year. Of the retail sales of goods, in 2013, the amount of enterprises (units) above designated size was 11070.4 billion Yuan, up 12.7 percent, year-on-year. Hence, the amounts of the retail sales reflect that Chinese retail market is huge. The increasing numbers reflect that market still have huge potential for growth. Chinese huge purchasing power attracts Wal-Mart to invest and expand more in China.

\subsubsection{Trade Barrier}

Obviously, trade friction is inevitable in many countries. However, at the 16th EU-China Summit, the European Union and China made a bilateral investment agreement. China is ready to comply with its international convention and develop a long-term vision of cooperation with European Union. It aims to boost bilateral investment by providing transparency, legal certainty and liberalization. It is better to protect investors and investments [4] According to Chart 1, it can see that the increasing EU exports are still higher than it imports from 2010 to 2012. Similarly, outward investment is also more than inward investment in 2011. It is directly proved that EU pays attention to China in trade in services and foreign direct investment (Figure 1). 


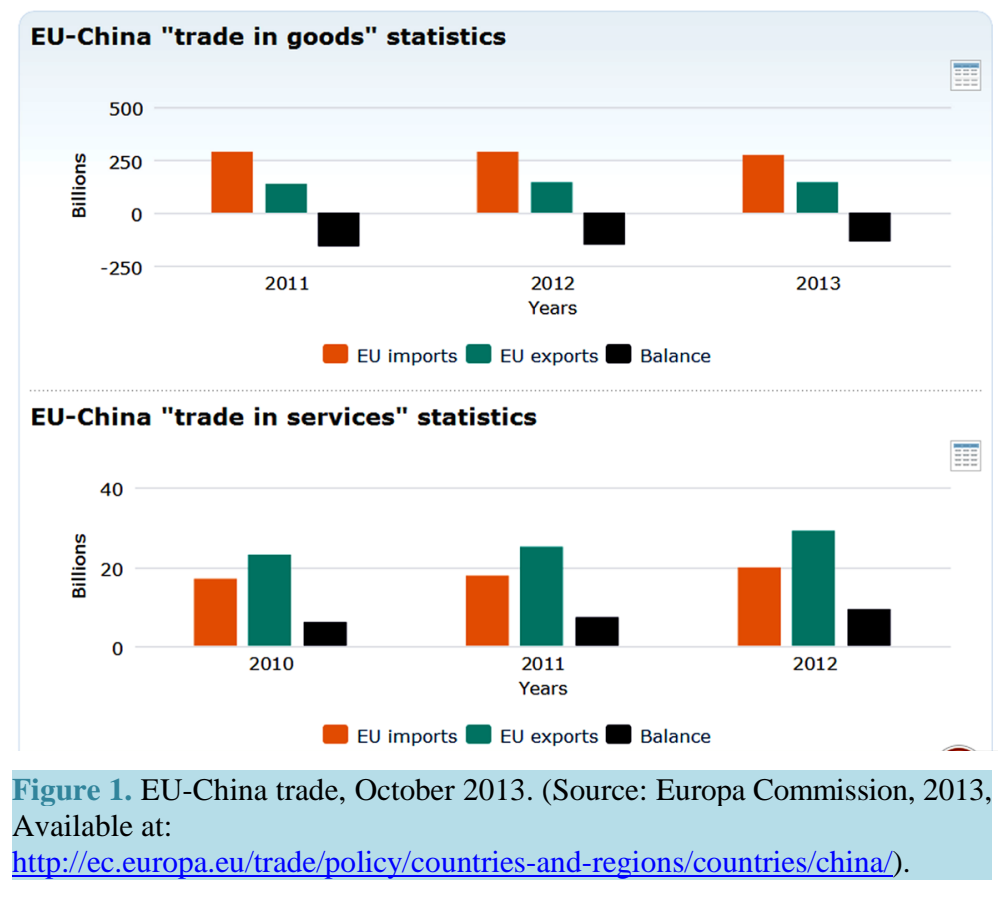

\subsubsection{Government Policy}

China has been quite open for FDI in almost all manufacturing and most service industries. Firstly, China is still strengthening institutional capacity. For example, China will set up “one-stop” facilities. It helps investors finish all procedures in one place. It ensures the efficiency of administration and operation in the approval process. Chinese government is committed to create open and transparent environment for healthy competition for FDI with transnational corporation. Secondly, China adjusts its economy and upgrades the value chain, attracting environmentally sustainable, energy efficient, and technologically advanced industries.

\subsection{Internalization Advantages}

Internalization, the third strand of Dunning's taxonomy, is regarded as the most important. Ethier (1986) pointed out that "Internalization appears to be emerging as the Caesar of the OLI triumvirate”. Coase (1937) argued that the optimal scale of the firm, or the optimal degree of internalization, reflects a balance between the transactions costs of using the market and the organizational costs of running a firm.

Dunning (2001) pointed out that the condition of internalization are a signed and executed contract need high cost; the buyer the value of the technology sales uncertainty; the need to control the use of products. Wal-Mart began with internalization program. For example, it bought stock from other companies and invested. Recently, it also plans e-commerce program.

The World Bank Group (2010) published report that Chinese laws and regulations are drawback, such as contact. It is difficult to protect the intellectual and brand property of foreign enterprises. Internalization should be focused on by Wal-Mart.

\section{Porter Diamond Model}

In 1990, Michael Porter established a new analysis standard about the nation competitiveness, i.e. the "Diamond Model” [5]. Porter's diamond model includes four basic decisive factors (factor conditions, demand conditions, the enterprise strategy, structure and rivalry and related and supporting industries) and 2 assistant factors (opportunity and government). These factors are important to analyze the industry competitive ability (Figure 2).

\subsection{Factor Conditions}

Porter (1990) pointed out that factor conditions are production factors of a country. It includes human resource, 


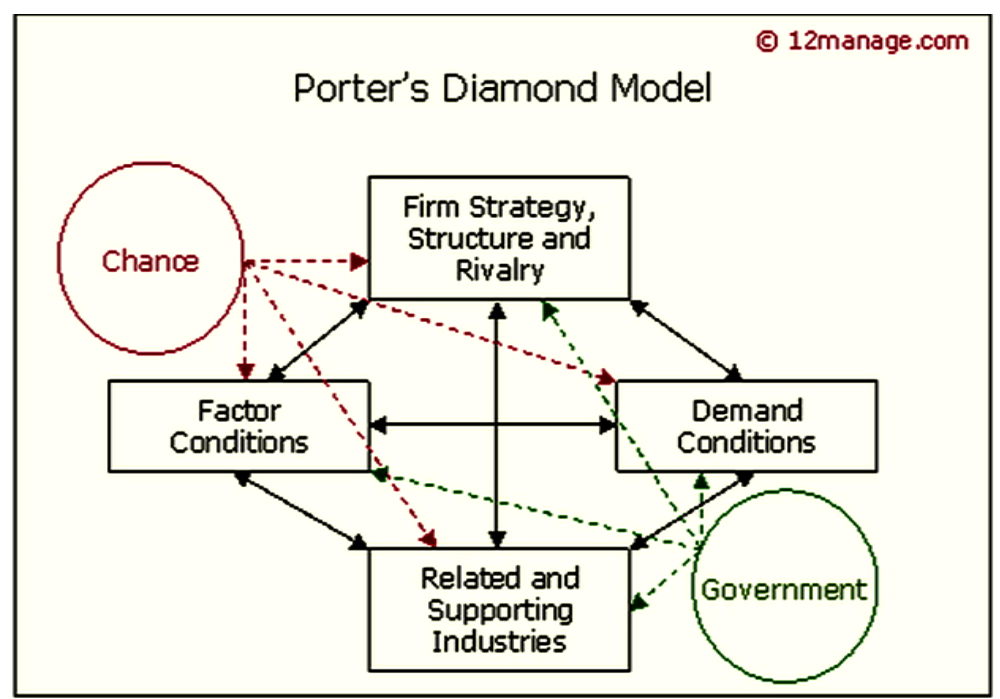

Figure 2. Diamond model. (Source: 12 Manage, 2014, available at: http://www.12manage.com/methods_porter_diamond_model.html).

knowledge resource, capital resource and infrastructure resource and natural resource. China's attractiveness for FDI depends on its development of infrastructure, resource availability (physical and labor), productivity and workforce skills, and the development of the business value chain (Dumon, 2009).

Firstly, it is about human resource. Ministry of Education in China (2014) offered the data that Chinese college graduates are 727 million in 2014. The number of universities is comparable to developed countries. So China have encourage talent resource (knowledge resource).

Secondly, it is about labor. China, a huge country, has 1.3 billion populations. China has strong and effective mobilizing resources. There is a case. Dortmund in German engaged 400 Chinese workers in 2006. German feel shock for the work force of Chinese. Chinese income is one-tenth of German. However, Chinese can take 12 hours to work every day. The Chinese productiveness is two times than German (360 doc, 2006).

Finally, it is about infrastructure. Roads, highways, bridges and other forms of physical infrastructure should be present, maintained and provide sufficient safety for the transportation of goods as well as for the commute of employees. The Ministry of Transport of China updated statistics that the total distance of road is 4237.5 thousand Kilometers, increased by 131.1 thousand Kilometers than a year earlier. Government invested about 1.3trillion Yuan for building road, increased by 0.9\% than in 2012.

\subsection{Demand Conditions for Products}

China, the world's No. 2 economy, is an important growth market when the US and European economies are in recession. China’s retail sales increased $15 \%$ to $\$ 783.03$ billion in the first quarter, according to the country’s National Bureau of Statistics. Chinese retail market is expected to grow $11 \%$ from this year to about $\$ 1.5$ trillion in 2015, compared with $4.2 \%$ growth in the US over the same period, according to the Institute of Grocery Distribution, a food-industry research firm [6]. Hence, Wal-Mart will have more confidence to expand their business in China.

\subsection{Related Supporting Industries}

China can effectively mobilize resources for aggiornamento. China with a population of 1.3 billion has the advantages of experienced manufacturing. Western and Japanese media iteratively admire the quality of Chinese labor (better educated, more willing to learn, disciplined). The Pearl River Delta, Chinese famous manufacturing zone, specializes in labor intensive manufacturing, production of spare parts and their assembly. There are capital intensive industries in Yangtze River Delta in China. China also constantly invest to safeguard new industries and great infrastructures, competed with few developing countries. Hence, these contribute to support WalMart's producing, operating and controlling cost. 


\subsection{The Firm Strategy, Structure and Rivalry}

\subsubsection{Firm Strategy}

Duke, Wal-Mart Stores Chief, said Wal-Mart's electronic commerce business increased by 30 percent in the first half of 2013. It is believed that E-commerce still contributes to Wal-Mart to grow globally. Wal-Mart intends to profit from China's various retail marketing through e-commerce. Between 2012 and 2015, it is expected to achieve goal which is 32 percent composite annual growth, according to Bain \& Co. Indeed, customers desire to see satisfying price and the safety of the products they are purchasing. E-commerce has been accepted by Chinese customers. Hence, E-commerce has been new strategy of Wal-Mart.

\subsubsection{Competitive Opponents}

The Kantar World panel is a British research firm. It offered relevant data. It is first to see Wal-Mart. Wal-Mart Inc. kept up the largest general store in China, holding a 7.7\% market share and attracting 27 percent of Chinese households. Wal-Mart haves 346 stores and six Sam’s Clubs in 128 cities across the country. It now holds a 35 percent stake and an additional 30 percent of voting rights in Trust-Mart, one of the top retailers in southern China. Secondly, RT-Mart International Ltd, a Taiwan-headquartered company, was the biggest grocer in China, taking 6.3 percent market share, reaching more than one-fourth of families in the mainland market. RT-Mart now has 161 stores on the mainland. Thirdly, the French retail giant Carrefour Group, the world's second-largest retailer by revenue in China. Carrefour took a 4.9 percent market share and has 187 stores. Finally, Tesco Plc., the world's third-largest by revenue, with a 2.1 percent market share in China. Tesco now has 96 supermarkets and 12 convenience stores on the Chinese mainland. Comparing these four supermarkets; it can find that other three are potential threat to Wal-Mart, especially RT-Mart. Hence, Wal-Mart should keep cautious attitude even though it now is in the lead.

\subsection{Government}

Chinese government performs policies to supporting state-owned enterprise at the cost of private enterprise, it can be adverse to attract FDI. Because Transnational Corporations need to cost additional time and money to obey regulations and policies, it impedes development of enterprises. Hence, Chinese government constantly adjusts and optimizes policies, favoring foreign enterprises.

Secondly, State is in social unrest and turmoil against business. For economic instability, it can also lead to runaway inflation which the currency can be obsolete. However, China keep political and economic stability. Stable environment for enterprises enhance confidence for FDI.

Thirdly, Chinese justice system still combat corruption of law enforcement agencies and counterfeit products for the efficacy of conducting trade activities.

\subsection{Chance}

China accounts for just 2-3\% of overall European investments abroad. While there are many challenges, Chinese market and rapid development also continues to offer huge opportunities, with significant potential for further expanding trade and investment and strengthening of the relations (European Commission, 2013). Wal-Mart as the third largest public corporation in the world should grasp the superexcellent opportunity and takes its advantages to expand an emerging market in China.

\section{Conclusions}

Nowadays, the Wal-Mart gets great success and grows to an efficient scale, which is mainly because the Wal-Mart evaluated the Chinese market as an emerging market accurately years ago. What's more, the advantage of the Wal-Mart also plays a big role, which includes the big scale, favorable finance unique technical and advanced management. The factors of labor market and the government's support in the emerging markets are important for TNCS's success. According to the above analysis, there are some main advantages in Chinese market. Firstly, Chinese labor pool is huge and flexible, and Chinese supply chain is sophisticated and supple, what's more, China encourages talent resource, hence, the Wal-Mart can get high quality human resources in Chinese market. Secondly, Chinese retail market is huge, Chinese market still have huge potential for growth, such huge purchasing power attracts Wal-Mart to invest and expand more in China. Thirdly, China has been 
quite open for FDI in almost all manufacturing and most service industries, Chinese government constantly adjusts and optimizes policies, favoring foreign enterprises and China also keeps political and economic stability, all of which can support Wal-Mart's producing, operating and controlling cost.

In conclusion, the main factors should be considered by TNCS to choose a country as emerging market, and this paper mainly researches, concludes the situation of the transnational corporation (scale finance technology management, the stability of economic and political, the labor resource of the country, the country market potential, and the government policy) and the laws related supporting industries optimizes policies. The analysis process in this paper can help some transnational corporations to understand Chinese market more, and get ideas for TNCS to evaluate whether a country is qualified for an emerging market more efficiently.

\section{References}

[1] Neary, J.P. (2009) Trade Costs and Foreign Direct Investment. International Review of Economics \& Finance, 2, 207-218.

[2] Statistic Brain (2013) Wal-Mart Company Statistics. http://www.statisticbrain.com/wal-mart-company-statistics/

[3] University Alliance (2014) Walmart: Keys to Successful Supply Chain Management. http://www.usanfranonline.com/resources/supply-chain-management/walmart-keys-to-successful-supply-chain-manage ment/\#.U8NZ9pSSxXu

[4] European Commission, 2013, China. http://ec.europa.eu/trade/policy/countries-and-regions/countries/china/

[5] Porter, M.E. (1990) The Competitive Advantage of Nations. Macmillan, London.

[6] Burkitt, L. (2012) Wal-Mart to Work Harder on Growth in China. http://online.wsj.com/news/articles/SB10001424052702304356604577340912309012378 
Scientific Research Publishing (SCIRP) is one of the largest Open Access journal publishers. It is currently publishing more than 200 open access, online, peer-reviewed journals covering a wide range of academic disciplines. SCIRP serves the worldwide academic communities and contributes to the progress and application of science with its publication.

Other selected journals from SCIRP are listed as below. Submit your manuscript to us via either submit@scirp.org or Online Submission Portal.
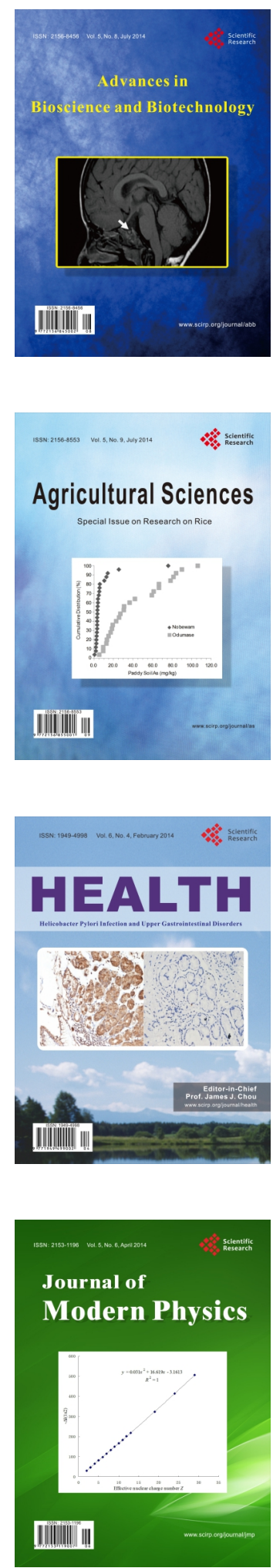
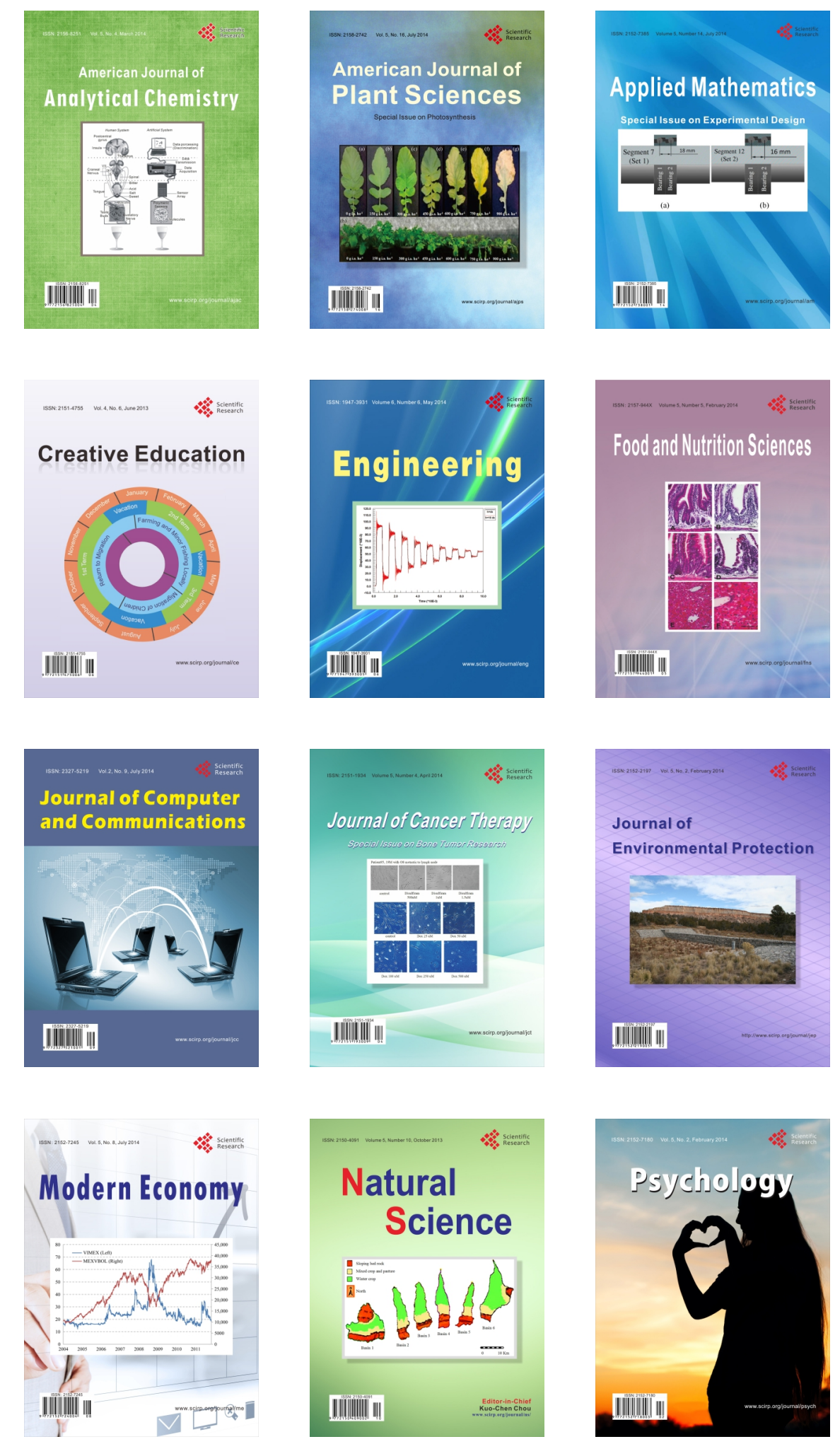